\title{
RHABDOID CHOROID PLEXUS CARCINOMA
}

\section{A rare histological type}

\author{
Martha Lilia Tena-Suck', Juan Luis Gómez-Amador ${ }^{2}$, Alma Ortiz-Plata', \\ C. Salina-Lara ${ }^{1}$, Daniel Rembao-Bojórquez ${ }^{1}$, Rosalba Vega-Orozco' ${ }^{1}$
}

\begin{abstract}
Primary central nervous system atypical teratoid/rhabdoid tumors mostly occur during early childhood and are almost invariably fatal. These tumors show similar histological and radiological features to primitive neuroectodermal tumor, meduloblastoma and choroid plexus carcinoma, but present different biological behaviors. We present the case of an 18 year-old man who presented headache, vomiting and ataxia. CT-scan and MRI revealed a posterior fossa tumor. A gross total resection was performed. An intraoperative study showed papillary-like tumors with large cells and mitotic features. Histological examination showed two different main growth patterns: solid sheets of undifferentiated polygonal cells with papillary features and rhabdoid cells. Immunohistochemically, these rhabdoid cells were positive for vimentin, epithelial membrane antigen, smooth-muscle actin, cytokeratin, S-100 protein, and glial fibrillary acidic protein. Electro-microscopically, the typical rhabdoid cells contained whorled bundles of intermediate filaments in their cytoplasm. A rhabdoid tumor is a clinicalpathological entity and emphasizes the necessity to distinguish this unique tumor from other pediatric central nervous system neoplasms. Cytopathological features, immunohistochemistry and electro-microscopy differential diagnoses are discussed.
\end{abstract}

KEY WORDS: choroid plexus tumors, imunohistochemistry, rhabdoid/teratoid tumor, rhabdoid features, rhabdoid carcinoma.

\section{Carcinoma de plexus coroides de tipo rabdoide: un tipo histológico raro}

RESÚMEN - Los tumores de tipo rabdoide primarios en cualquier sitio son raros y en el sistema nervioso central son extremadamente raros y ocurren principalmente en niños, el tumor teratoide/rabdoide es el tumor más frecuente dentro de este grupo y de evolución clínica fatal. El tumor neuroectodermico primitivo, medulobalstoma y al carcinoma de plexos coroides son tumores generalmente muestran aspectos clínicos radiológicos e histológicos similares, con evolución diferente. Presentamos el caso de un hombre joven de 18 años que inició con cefalea vómitos y ataxia. La imagen de TC muestra tumor en fosa posterior. Se realizó resección total del tumor. En el estudio transoperatorio se observó neoplasia maligna de células grandes con mitosis y que formaba estructuras papilares. Histológicamente se observaron dos patrones diferentes, uno formado por nidos sólidos de células poligonales indiferenciadas con formación de estructuras papilares y el otro con abundantes células grandes de aspecto rabdoide. Por inmunohistoquímica las células de aspecto rabdoide fueron positivas para vimentina, antigeno de membrana epitelial, actina de músculo liso, citoqueratina, y proteína S-100, La PGAF fue focalmente positiva. Se realizó microscopía electrónica de las células rabdoides que mostraban nidos irregulares de filamentos intermedios intracitoplasmicos y lamina basal. El tumor rabdoide cerebral es clínica como histológicamente una rara entidad en la población pediátrica. Se discute el aspecto citopatológicas de inmunohistoquímica y de microscopia electrónica y sus diagnósticos diferenciales.

PALABRAS-CLAVE: tumores del plexo coróide, tumor rabdoide/teratoide, carcinoma rabdoide, imunohistoquímica.

In the central nervous system (CNS), most rhabdoid tumors occur in the posterior fossa of very young children ${ }^{1-5}$. The histological diagnosis of a malignant rhabdoid tumor depends on the identification of characteristic rhabdoid cells (large cells with eccen- trically located nuclei and abundant, eosinophilic cytoplasm), and immunohistochemistry, with positive antibodies to vimentin, keratin and epithelial membrane antigen ${ }^{2,3,6,9}$. The differential diagnosis includes meduloblastoma, primitive neuroectodermal tumor,

Instituto Nacional de Neurología y Neurocirugía, México City, México: ${ }^{1}$ Department of Neuropathology; ${ }^{2}$ Department of Neurosurgery.

Received 17 July 2006, received in final form 23 March 2007. Accepted 8 May 2007.

Dra. Martha L. Tena Suck - Departamento de Neuropatología / Instituto Nacional de Neurología y Neurocirugía "Manuel Velasco Suárez" - Av Insurgentes Sur 3788 Col. La Fama, Tlalpan - cp. 14269 México, D.F. - México. E-mail: tenasuck@yahoo.com 

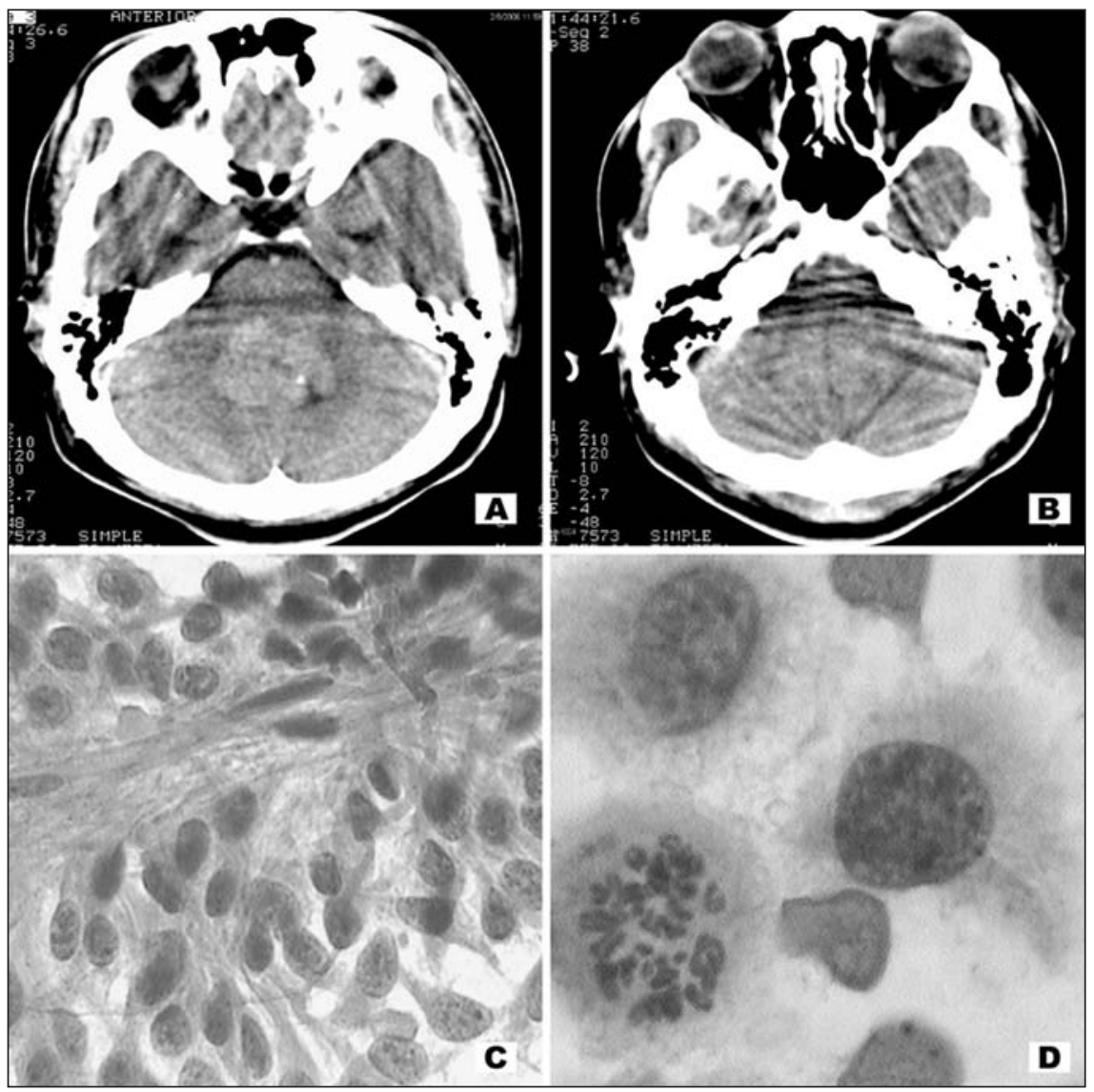

Fig 1. (A) CT-scan showed a floor of fourth ventricle tumor. (B) CT-scan control, post-chirurgical procedure no tumor was found. (C) Cytology of intraoperative smear showed a median cell forming papillary features (H\&E original magnification x100). (D) Median and large tumor cells with abundant fine granular cytoplasm, with cytoplasmic degenerative vacuoles, the nuclei were large and irregular with prominent nucleoli. Mitosis features were seen (H\&E original magnification $\times 400$ ).

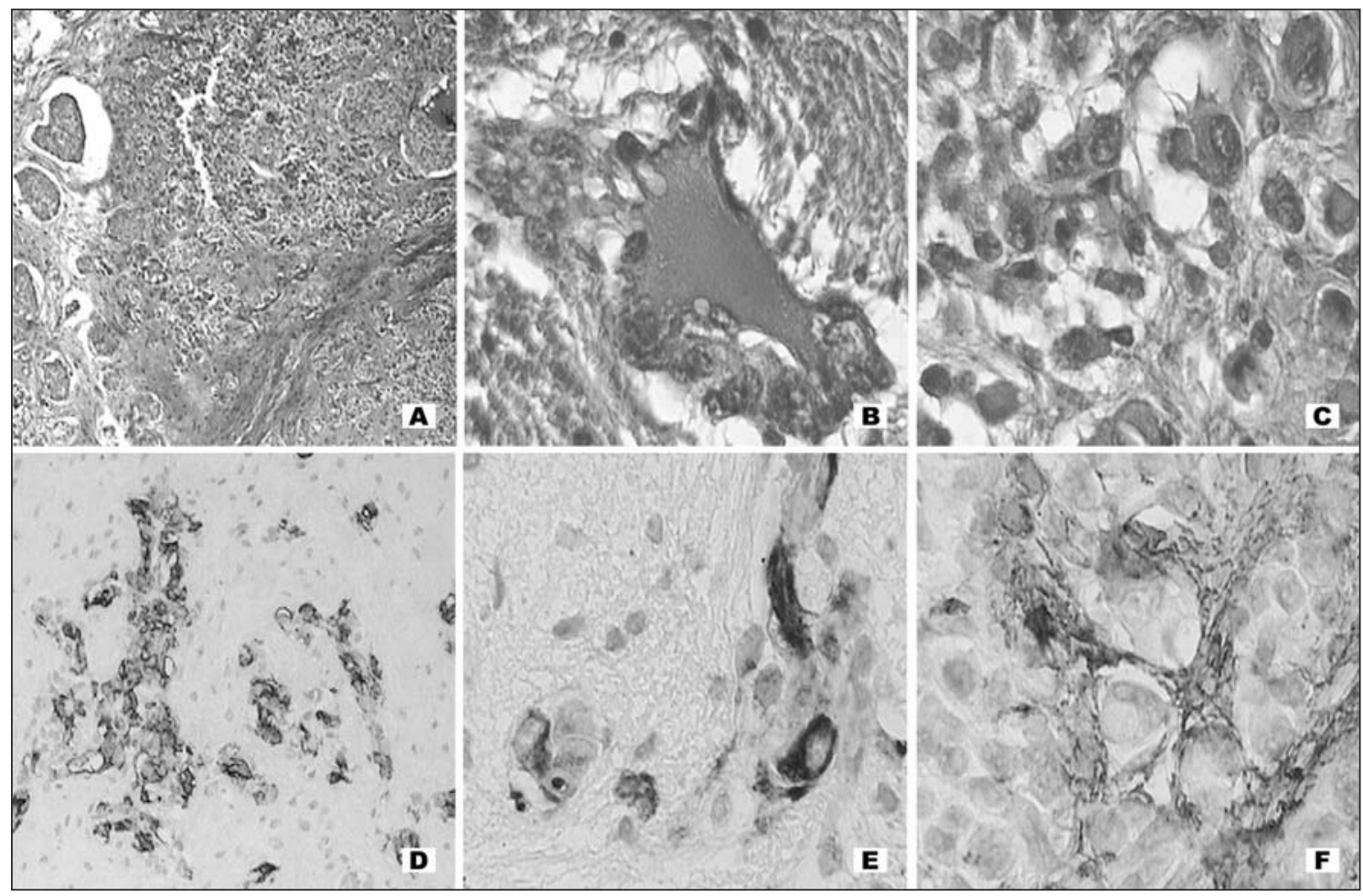

Fig 2. (A) Tumor histopathological findings showed epithelial cells that formed. (B) Papillary structures and diffuse sheet of atypical "rhabdoid" cells. (C) It showed a sheet of atypical "rhabdoid" cells with discrete cell borders, eccentric nuclei, and abundant eosinophilic cytoplasm and well-demarcated globular inclusion (H\&E original magnification x200). (D) EMA was immunoreactive in rhabdoid cell (IHC, original magnification x200). (E) Rhabdoid cells were Vimentin positive (IHC stain, original magnification x400), and (F) GFAP immunoreactions (original magnification x200). 


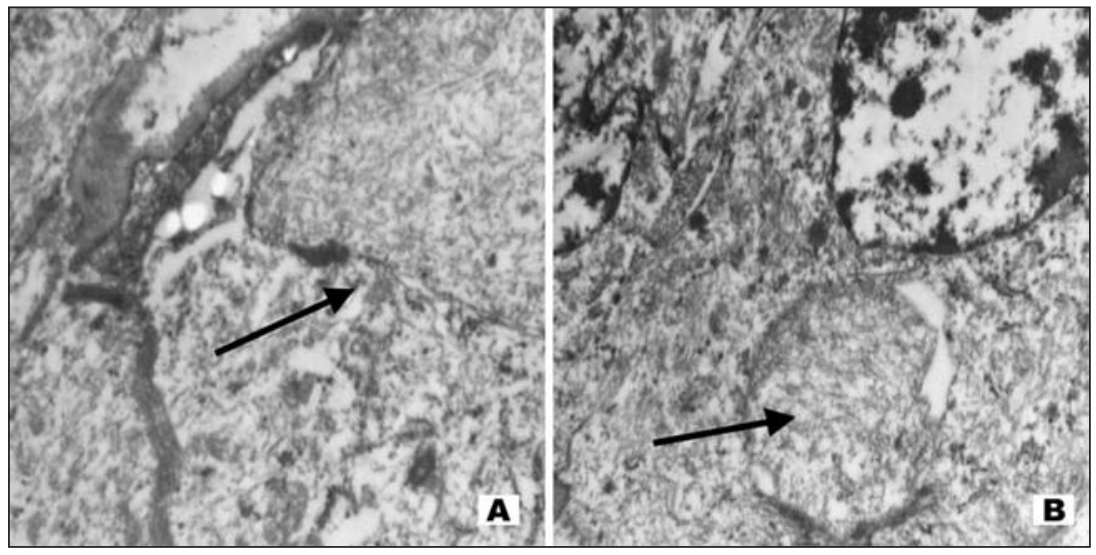

Fig 3. (A) Electron micrograph showing cells with cytoplasm intermediate filaments (large arrow). Occasional desmosomes can be observed (head arrows). (B) Typical rhabdoid cell with concentric arrangement of intermediate filaments (arrow) (Uranyl Acetate-Lead Citrate, 17.520X). ependymoma, choroid plexus carcinoma and malignant glioma ${ }^{6-9}$. Rhabdoid choroids plexus carcinoma is a rare tumor occurring in young children. Immunophenotype stains showed focal positivity for cytokeratin, epithelial membrane antigen, glial fibrillary acidic protein, S100, and vimentin $n^{6,7,9}$. The MIB-1 index ranged from $7.0 \%$ to $27.1 \%$ and the $\mathrm{p} 53$ was usually positive ${ }^{2}$. Electron microscopy shows choroid plexus differentiation and the co-existence of rhabdoid cells. Usually, there are deletions of chromosome $22^{2,7-9}$. Thus, there is a phenotypic and genotypic overlap between choroid plexus carcinomas and rhabdoid tumors².

We report a rare case of rhabdoid choroid plexus carcinoma with histological, immunohistochemical, and ultrastructural features showing similar characteristics to rhabdoid/teratoid tumor; however, the crush intraoperative cytopathological study showed differences.

\section{CASE}

An 18-year-old man with an unremarkable history presented a 12-month headache, nausea, vomiting; 8 months later, visual disturbance, diplopia, ataxic gait, and left hemiparesis. In urgency admission, he presented a severe headache, amaurosis and a diadococcinesia. During neurological examination, he presented weakness in the legs, bilateral papilledema and decreased vision.

CT-scan showed an intra-axial solid isointense tumor, located in the floor of the fourth ventricle, with cortex images with intense contrast enhancement and hydrocephalus (Fig 1A).

A craniotomy was performed and a total resection was made. Post-operatory CT-scan confirmed gross total excision (Fig 1B). Cytological examination of the intraoperative crush study revealed a clustered large tumor with cells with abundant finely granular cytoplasm and cytoplasmic vacuoles (Figs $1 C$ and $1 D$ ). The nuclei were large and irregular with prominent nucleoli. Mitosis features were seen. The chromatin was coarsely granular with sub-membranous condensation, and nuclei eccentrically located, also binu- cleated and multinucleated tumor cells were found (Figs $2 \mathrm{~A}, 2 \mathrm{~B}$ and $2 \mathrm{C}$ ). The diagnosis of choroid plexus carcinoma was made.

Histopathology - Brain tumor tissue was formalin fixed, and paraffin embedded. Four $\mu \mathrm{m}$-thick sections were stained by routine histological technique (H\&E). Light microscopy revealed a tumor composed by epithelial cells that formed papillary structures and diffuse sheet of atypical "rhabdoid" cells with discrete cell borders, eccentric nuclei, abundant eosinophilic cytoplasm and well-demarked globular inclusion (Figs 3A and 3B). Hipervascular proliferation and necrotic areas were found. Psammoma bodies and lymphocytes were not found. Conventional immunohistochemistry showed positive cells to cytokeratins, epithelial membrane antigen (EMA), and vimentin with membranous staining in the polygonal tumor cells. Rhabdoid cells showed strong cytoplasmic staining for vimentin and were focally positive for EMA, GFAP and S-100 protein (Figs 2D, $2 E$, and 2F). Stain for cytokeratin, AFP, $\beta G H, P L P, E C E$, muscle-actin, desmin, ENE, sinaptophysin, myoglobin, HMB45, melan A were negative. A proliferative index as determined by MIB-1 was $25 \%$ and PCNA index was $66 \%$.

Tissue fragments included in the paraffin block were used to perform transmission electron microscopy. At that level, we could observe fixing and processing artifacts in the epithelial cells, since the samples were taken from a paraffin block. The typical rhabdoid cells contained whorled bodies of (bundles) packed intermediate filaments in their cytoplasm. Occasionally, such rhabdoid cells were partially covered by basal lamina at their stromal interface and desmosomes (Figs 3A and 3B), however, cytogenesis and molecular studies were not carried out in our patient.

Three months after the surgery, the patient presented weakness in the legs, left hemiparesis and headache. He had not received chemotherapy. Two years later, he is alive.

\section{DISCUSSION}

Rhabdoid phenotypic change has been described in a number of different neoplasms from diverse organ sites. These tumors share common light and elec- 
tron-microscopic features display a polyphenotypic immunohistochemical profile and often show cytogenetic abnormalities of chromosome $22^{1}$.

The recognition of polyphenotypic high-graded malignancies has been published and concerns the posterior fossa neoplasms that express neural, epithelial, myogenic, and glial markers, including synaptophysin, neurofilament, vimentin, glial fibrillary acidic protein, S-100, neuron-specific enolase, desmin, $\mathrm{S}$ antigen, MIC2, cytokeratin, epithelial membrane antigen, and carcinoembryonic antigen. Rhabdoid cells showed a divergent differentiation ${ }^{6}$. Some of these tumors have been regarded as variants of primitive neuroectodermal tumor (PNET) or as extra renal malignant or atypical rhabdoid tumors ${ }^{6}$.

Infrequently, other rhabdoid tumors of the CNS have been described, including rhabdoid meningiomas, glioma, PNET, meningioma, ependymoma, choroid plexus carcinoma, sarcoma, and germ cell tumor $^{7,9-12}$.

The cytoplasm of the larger cells was conspicuous and presented a "rhabdoid-like" appearance; rhabdoid features were not always prominent, though. Epitheloid features in the form of poorly formed glands or Flexner-Winter rosettes and papillary features are noted in a minority of cases ${ }^{9,12}$. Honda et al. ${ }^{12}$ published a rare case of cerebral composite atypical teratoid/rhabdoid tumor and yolk sac tumor in the frontal lobe of an infant. It is known that some tumors derived from the yolk sac may present rare papillary formations. In our case, it drew our attention that they were negative for AFP, ACE, LP and that Schiller-Duval bodies in a myxoid matrix like the case published by Honda et al. were not present ${ }^{12}$.

Poorly differentiated choroid plexus carcinomas contained cells displaying a rhabdoid phenotype. Immunohistochemically, cytokeratin and vimentin are expressed by virtually all choroid plexus papillomas and most choroid plexus carcinomas, while transthyretin and S-100 protein are present in $80-90 \%$ of cases, less frequently, though, in choroid plexus carcinoma ${ }^{13,14}$. Glial fibrillary acidic protein can be focally found in about $25-55 \%$ of choroid plexus papillomas and $20 \%$ of choroid plexus carcinomas ${ }^{14-18}$.

CNS atypical teratoid/rhabdoid tumor (AT/RT) and choroid plexus carcinoma (CPC) are rare highly malignant tumors that predominantly arise in infants and young children ${ }^{1-5}$. Overlapping clinical, histological, ultrastructural, or immunohistochemistry features may obscure the diagnosis in some cases ${ }^{18}$. Atypical teratoid/rhabdoid and considerable pathologic, cyto- genetic and molecular characterizations have been accomplished and provide insight into the possible molecular etiology of the disease and malignant rhabdoid tumors that occur outside the $\mathrm{CNS}^{18}$. It occurs primarily in early childhood but the true incidence of the disease is not yet known ${ }^{9,19}$.

Judkins et al. ${ }^{20}$, supported in their study that the immunohistochemical staining for INII gene expression as an ancillary tool for the evaluation of cases in which overlapping histological and immunohistochemical phenotypes is determinant for CPC vs AT/ RT. INII is most often retained in CPC and it is lost in AT/RT.

Ultrastructural analyses may help to differentiate them. AT/RT tumors cells contained aggregates of cytoplasmic intermediate filaments, and one of the more important features of these cells is the presence of basal lamina ${ }^{18}$. Cells with interdigitating cytoplasmic borders were seen and rare cells had microtubules $^{21}$. The typical rhabdoid cells contained whorled bundles of intermediate filaments in their cytoplasm. Occasionally, such rhabdoid cells were partially covered by basal lamina at their stromal9,21,22.

Using electron microscopy, the choroid plexus carcinoma shows cells with different shapes, the shape of the nuclei varied from an oval one to an irregular one with many indentations. The chromatin is clumped around the periphery of the nuclei ${ }^{18}$. The neoplastic cells contained numerous free ribosomes, glycogen granules, and rough endoplasmic reticulum. The apical cell surfaces showed various sizes of club-like or roundish microvilli filled with glycogen granules, and rarely $9+2$ cilia. Elongated functional complexes were occasionally seen near the apical ends ${ }^{18}$. The basal portions of the cells had a continuous basement membrane ${ }^{9}$. However, Felix et al. ${ }^{23}$, reported that both, choroid plexus papillomas and carcinomas, displayed cytoplasmic intermediate filaments and desmosomes.

Lu et al. ${ }^{23}$ published a cytological examination of CSF from a patient with AT/R and reported a large size of the tumor cells, eccentricity of the nuclei, and prominent nucleoli. Cytomorphological features consisted of hypercellularity, predominantly large tissue fragments with tumor cells surrounding proliferating capillaries depicting a "papillary-like" appearance; large, round, "plasmacytoid" cells and characteristic "rhabdoid" cells with granular to fibrillary, brightly eosinophilic cytoplasm with or without globoid "inclusions"; large, eccentrically located, round-to-reniform nuclei with single prominent nucleoli ${ }^{24,25}$. 
The differential diagnosis includes; meduloblastoma, primitive neuroectodermal tumor, choroid plexus carcinoma, and malignant glioma ${ }^{24,25}$.

The choroid plexus carcinomas cytological characteristics have been reported in a few cases, even though we consider that these characteristics correspond to epithelial atypical cells with a large amount of cytoplasm, which look like carcinoma cells and do not belong to the described rhabdoid tumor cells $s^{7,9,18,24,25}$.

In conclusion, rhabdoid phenotypic change has been described in a number of different neoplasms from diverse organ sites. We present the case of an 18-year old young man with a choroid plexus rhabdoid carcinoma. In the immunohistochemical panel, it had the same pattern as the teratoid rhabdoid tumor in several other cases. Ultra structurally, it demonstrates epithelial cells with intermediate filaments. Even though the cytological study performed during surgical procedure showed a papillary pattern with a large amount of capillaries, large cells with fine chromatin and a prominent nucleus, binucleated cells with abundant densely eosinophilic cytoplasm seemed identical to the ones reported in the rhabdoid tumor. Cytologically, these cells corresponded to epithelial atypical cells, characteristic to choroids plexus carcinoma. The cytomorphological feature was unique and lead to an accurate diagnosis in the right clinicoradiologic context.

\section{REFERENCES}

1. Ogino S, Ro TY, Redline RW. Malignant rhabdoid tumor: a phenotype? an entity? A controversy revisited. Adv Anat Pathol 2000;7:181-190.

2. Lee MC, Park SK, Lim JS, et al. Atypical teratoid/rhabdoid tumor of the central nervous system: clinico-pathological study. Neuropathology 2002;22:252-260.

3. Fujisawa H, Misaki K, Takabatake Y, Hasegawa M, Yamashita J. Cyclin D1 is overexpressed in atypical teratoid/rhabdoid tumor with hSNF5/ INI1 gene inactivation. J Neurooncol 2005;73:117-124.

4. Taylor MD, Gokgoz N, Andrulis IL, Mainprize TG, Drake JM, Rutka JT. Familial posterior fossa brain tumors of infancy secondary to germline mutation of the hSNF5 gene. Am J Hum Genet 2000;66:1403-1406.

5. Muthuphei MN. Divergent differentiation in choroid plexus papilloma: an immunohistochemical study of five cases. Cent Afr J Med 1995; 41:103-104
6. Jay V, Edwards V, Halliday W, Rutka J, Lau R. "Polyphenotypic" tumors in the central nervous system: problems in nosology and classification. Pediatr Pathol Lab Med 1997;17:369-389.

7. Lutterbach J, Liegibel J, Koch D, Madlinger A, Frommhold H, Pagenstecher A. Atypical teratoid/rhabdoid tumors in adult patients: case report and review of the literature. J Neurooncol 2001;52:49-56.

8. Burger PC, Yu IT, Tihan T, et al. Atypical teratoid/rhabdoid tumor of the central nervous system: a highly malignant tumor of infancy and childhood frequently mistaken for medulloblastoma: a Pediatric Oncology Group study. Am J Surg Pathol 1998;22:1083-1092.

9. Wyatt-Ashmead J, Kleinschmidt-DeMasters BK, Hill DA, et al. Rhabdoid glioblastoma. Clin Neuropathol 2001;20:248-255.

10. Ho DM, Hsu CY, Wong TT, Ting LT, Chiang H. Atypical teratoid/rhabdoid tumor of the central nervous system: a comparative study with primitive neuroectodermal tumor/medulloblastoma. Acta Neuropathol (Berl) 2000;99:482-488.

11. Keppes JJ, Moral LA, Wilkinson SB, et al. Rhabdoid transformation of tumors cells in meningioma: a histologic indication of increased proliferativa activity. Am J Surg Pathol 1998;22:231-238.

12. Honda M, Baba H, Yonekura M, Iseki M. Cerebral composite atypical teratoid/rhabdoid tumor and yolk sac tumor in the frontal lobe of an infant: case report. Neurol Med Chir (Tokyo) 2005;45:318-321.

13. Barreto AS, Vassallo J, Queiroz Lde S. Papillomas and carcinomas of the choroid plexus: histological and immunohistochemical studies and comparison with normal fetal choroid plexus. Arq Neuropsiquiatr 2004;62:600-607.

14. Mannoji H, Becker LE. Ependymal and choroid plexus tumors: cytokeratin and GFAP expression. Cancer 1988;61:1377-1385.

15. Gyure KA, Morrison AL. Cytokeratin 7 and 20 expression in choroid plexus tumors: utility in differentiating these neoplasms from metastatic carcinomas. Mod Pathol 2000;13:638-643.

16. Newbould MJ, Kelsey AM, Arango JC, Ironside JW, Birch J. The choroid plexus carcinomas of childhood: histopathology, immunocytochemistry and clinicopathological correlations. Histopathology 1995;26:134-137.

17. Rickert $\mathrm{CH}$, Paulus W. Tumors of the choroid plexus. Microsc Res Tech 2001;52:104-111.

18. Wyatt-Ashmead J, Kleinschmidt-DeMasters B, Mierau GW, et al. Choroid plexus carcinomas and rhabdoid tumors: phenotypic and genotypic overlap. Pediatr Dev Pathol 2001;4:545-549.

19. Gessi M, Giangaspero F, Pietsch T. Atypical teratoid/rhabdoid tumors and choroid plexus tumors: when genetics "surprise" pathology. Brain Pathol 2003;13:409-414.

20. Judkins AR, Burger PC, Hamilton RL, et al. INI1 protein expression distinguishes atypical teratoid/rhabdoid tumor from choroid plexus carcinoma. J Neuropathol Exp Neurol 2005;64:391-397.

21. Bhattacharjee M, Hicks J, Langford L, et al. Central nervous system atypical teratoid/rhabdoid tumors of infancy and childhood. Ultrastruct Pathol 1997;21:369-378.

22. Felix I, Phudhichareonrat S, Halliday WC, Becker LE. Choroid plexus tumors in children: immunohistochemical and scanning-electron-microscopic features. Pediatr Neurosci 1987;13:263-269.

23. Lu L, Wilkinson EJ, Yachnis AT. CSF cytology of atypical teratoid/rhabdoid tumor of the brain in a two-year-old girl: a case report. Diagn Cytopathol 2000;23:329-332.

24. Parwani AV, Stelow EB, Pambuccian SE, Burger PC, Ali SZ. Atypical teratoid/rhabdoid tumor of the brain: cytopathologic characteristics and differential diagnosis. Cancer 2005;25:65-70.

25. Raisanen J, Hatanpaa KJ, Mickey BE, White CL. Atypical teratoid/rhabdoid tumor: cytology and differential diagnosis in adults. Diagn Cytopathol 2004;31:60-63. 